\title{
SURFACE TEMPERATURE DYNAMICS IN RESPONSE TO LAND COVER TRANSFORMATION
}

\author{
Syed Riad Morshed, Md. Abdul Fattah, Asma Amin Rimi and Md. Nazmul Haque* \\ Department of Urban and Regional Planning, Khulna University of Engineering \& Technology, Khulna University of \\ Engineering \& Technology, Khulna-9203, Bangladesh.
}

\author{
Date received: 26/04/2020 Date accepted: 20/08/2020 \\ *Corresponding author's email: nhaque.kuet13@gmail.com \\ DOI: $10.33736 /$ jcest. 2616.2020
}

\begin{abstract}
This research assessed the micro-level Land Surface Temperature (LST) dynamics in response to Land Cover Type Transformation (LCTT) at Khulna City Corporation Ward No 9, 14, 16 from 2001 to 2019, through raster-based analysis in geo-spatial environment. Satellite images (Landsat 5 TM and Landsat 8 OLI) were utilized to analyze the LCTT and its influences on LST change. Different indices like Normalized Difference Moisture Index (NDMI), Normalized Difference Vegetation Index (NDVI), Normalized Difference Buildup Index (NDBI) were adopted to show the relationship against the LST dynamics individually. Most likelihood supervised image classification and land cover change direction analysis shows that about $27.17 \%, 17.83 \%$ and $4.73 \%$ buildup area has increased at Ward No 9, 14, 16 correspondingly. On the other hand, the distribution of change in average LST shows that water, vacant land, and buildup area recorded the highest increase in temperature by $2.72^{\circ} \mathrm{C}, 4.15^{\circ} \mathrm{C}, 4.59^{\circ} \mathrm{C}$, respectively. The result shows the average LST increased from $25.80^{\circ} \mathrm{C}$ to $27.15^{\circ} \mathrm{C}$ in Ward No $9,26.84^{\circ} \mathrm{C}$ to $27.23^{\circ} \mathrm{C}$ in Ward No 14 and $26.87^{\circ} \mathrm{C}$ to $27.12^{\circ} \mathrm{C}$ in Ward No 16 . Here, the most responsible factor is the transformation of land cover in buildup areas.
\end{abstract}

Copyright (C) 2020 UNIMAS Publisher. This is an open access article distributed under the Creative Commons Attribution-Non-commercial-ShareAlike 4.0 International License which permits unrestricted use, distribution, and reproduction in any medium, provided the original work is properly cited.

\section{Keywords: Land Cover Change, LST Dynamics, NDBI, NDMI, Raster Based Approach}

\subsection{INTRODUCTION}

The enormous population growth has resulted in the increase of new cities, industries, vehicles, and infrastructures. Urbanization and industrialization have been influenced in the drastic change of land cover types around the world. This has resulted in the extensive environmental changes around the world. Global warming, changes in ecosystems, climate change, greenhouse emissions, increase of sea level and many other problems are increasing day by day due to the massive transformation of land cover types [1]. The study aimed to identify how significantly the Land Surface Temperature (LST) responses to the change of Land Use Patterns (LUP) in some contiguous wards of a developing city. Environmental changes such as temperature, rainfall, LST and so on does not changes equally in all portions of the city because the development of change of land cover types do not changes equally in all directions. The city shows the overall different changes on a large scale. The study focused on identifying the micro levels (ward wise) change of LST and LUP of Khulna city. For these three adjacent wards, Ward No 9, Ward No 14 and Ward No 16 were selected in this study.

In Growth of the population has been increasing the need for new housing, workplace, education, food, and other basic needs along with the increase of human activities. Again, various activities are going on to improve the living standard of the people, which is exerting a negative influence on Land Cover Type (LCT). Human activities on a large scale are incessantly influencing in the massive transformation of LCT [2]. A huge percentage of water body vacant land, agricultural land, vegetation, wetlands are decreasing every day and transforming into buildup areas around the world. This massive Land Cover Type Transformation (LUTT) affecting the Surface Energy Budget (SEB) through altering the climate. One of the important parameters for estimating SEB is Land Surface Temperature (LST) through assessing land use and land cover (LULC) pattern changes [3]. Various methods and approaches are introduced by many researchers to measure and analyze the LST [4,5,6,7]. 
Due to urbanization and unplanned development resulted in a malignant loss of greeneries, vacant space, waterbodies, eco-system, and ecologically sensitive habitats [8]. Many houses, shopping malls, buildings, infrastructures are being built in every year. As a result of the unplanned urbanization, the sensitive areas are destroyed. People are building infrastructures wherever they wish, without thinking about the mother nature. As a result, the environment is deteriorating its balance. The earth's average temperature and the concentration of $\mathrm{CO}_{2}$ in the air is increasing, but the total average rainfall is decreasing. Since 1880, the global annual average temperature rose at an average rate of $0.07^{\circ} \mathrm{C}(0.13$ $\left.{ }^{\circ} \mathrm{F}\right)$ per decade [9]. According to Shahid [10], the mean temperature in Bangladesh has risen by $0.103^{\circ} \mathrm{C} /$ year during the period $1958-2007$ and for Khulna the rate was $0.007^{\circ} \mathrm{C} /$ year during $1960-2012$. But with the due to massive environmental change the mean temperature increasing rate stood at $0.04162^{\circ} \mathrm{C} /$ year in Khulna during 2003 to 2018 [11]. If the land use transformation continues in current rate, within 2050 the temperature will rise to $10 \mathrm{C}$ in Khulna and there will be no land to transform into build area.

Increase of buildup area reduces the heat reflection capacity of soil and soil starts to retain heat which increases the surface temperature. Destruction of waterbodies like river, ponds, wetlands, canals etc. and increase of buildup area prevents water from entering the deep soil. For which ground water level is declining and soil moisture retention capacity is decreasing. influencing in the decrease of Normalized Difference Moisture Index (NDMI) value [12] and rise of land surface temperature. Again, due to the destruction of greeneries and vegetation areas, the value of Normalized Difference Vegetation Index (NDVI) [13] decreases and increase of buildup area increases Normalized Difference Buildup Index (NDBI) value [14]. These three factors response mostly with the change of land use pattern and influences in the change of LST in any area and global LST rose from $0.6^{0} \mathrm{C}$ to $0.9^{0} \mathrm{C}\left(1.1^{0} \mathrm{~F}\right.$ to $\left.1.6^{0} \mathrm{~F}\right)$ during the year 1906 to 2005[11,15].

Many researchers have worked on the change of LST in Dhaka City in the literature $[16,17,18,19]$. Among all these researches, [16] calculated all the factors and indexes related to the change of the LST. Sharmin [20] showed the relationship between NDVI and LST. Kafy et. al. illustrated the land cover change and LST change in the Rajshahi City Corporation area in the literature [28]. These all research showed the influences of land use change in the change of Land surface temperature in a city or in a division that means in a large scale. But, the change of LUP does not occur uniformly over the city. LUP change is much higher in industrial areas of a city rather than in the residential areas and the vegetation areas. Again, the surrounding areas of the industrial areas have higher environmental temperatures rather than other areas of a city. So, the calculation of the change of LUP and LST in city scale does not show the accurate image of LST and LUP change of that city. In this study, the identification of LUP and LST change in the ward basis attempted to solve the problems in large scale LUP and LST change analysis. Again, the ward wise linear regression analysis between LST and NDVI, LST and NDWI, LST and NDBI has been conducted for both years. Determination of LST changes based on LUP and surface temperature change direction based on land use change direction has fulfilled many previous research limitations.

The rise of LST in Dhaka city has observed $3.2^{\circ} \mathrm{C}$ during the year 2002 to 2014 [18] and in case of Chittagong metropolitan area it is observed $3.81^{\circ} \mathrm{C}$ [20]. The change of average LST at the research study area was $3.43^{\circ} \mathrm{C}$ which is found almost same in the case of Dhaka, Chittagong, and Rajshahi City [21]. Due to the implementation of Padma Bridge and various development projects, communication system with Khulna city and other cities of the country will be developed. This will create new investment opportunities and therefore, the policy makers hope that the social, physical, and economic condition of Khulna will improve a lot. As a result, most of the areas of Khulna City are hoping to be turned into buildup areas. But unplanned urbanization, destruction of eco-friendly areas and high land cover transformation rate will lead to various environmental problems including the rise of LST and ecological imbalance in the city. As a result, living in this city will begin to unsuitable day to day. Various problems will increase including decrease of soil fertility, increase of soil salinity, lowering ground water levels 
etc. which will increase the suffering of the residence by reducing food production, increasing water crisis, and changing environment. This research will provide information to the people about the effect of unplanned development and unplanned land cover change on environmental change. Also inspire for further research on the micro level environmental change due to land use and land cover changes in Bangladesh.

\subsection{METHODOLOGY}

\subsection{STUDY AREA}

The study area was selected as three different wards, Ward No 9 Mujgunni, Ward No 14 Boyra and Ward No 16 Choto Boyra under Khulna City Corporation area (Figure 1). These three wards are located along the middle of KCC. In each ward, there are industrial areas, commercial areas along with residential areas. The total area of the study area is 2113.53 acres with a population of 87430 (BBS,2011). About $73 \%$ land use type across the study area is residential and most of these are in ward no $14 \& 16$. After the introduction of Mujgunni Residential Area, many buildings are being constructed at ward no 9. That is why the land cover change has been observed much higher in this area rather than in the surrounding wards. Although these three study areas are located side by side, but the maximum land use purposes of these three wards were different. Whereas most of the land cover in Ward No 9 was agricultural land, residential land in Ward No 16, buildup and open space in Ward No 14. In addition, the percentage of mixed land use areas in these wards are much higher than other wards of KCC [10,29]. That is why these three wards have been selected to find the micro level land surface temperature change with the conversion of land use type.
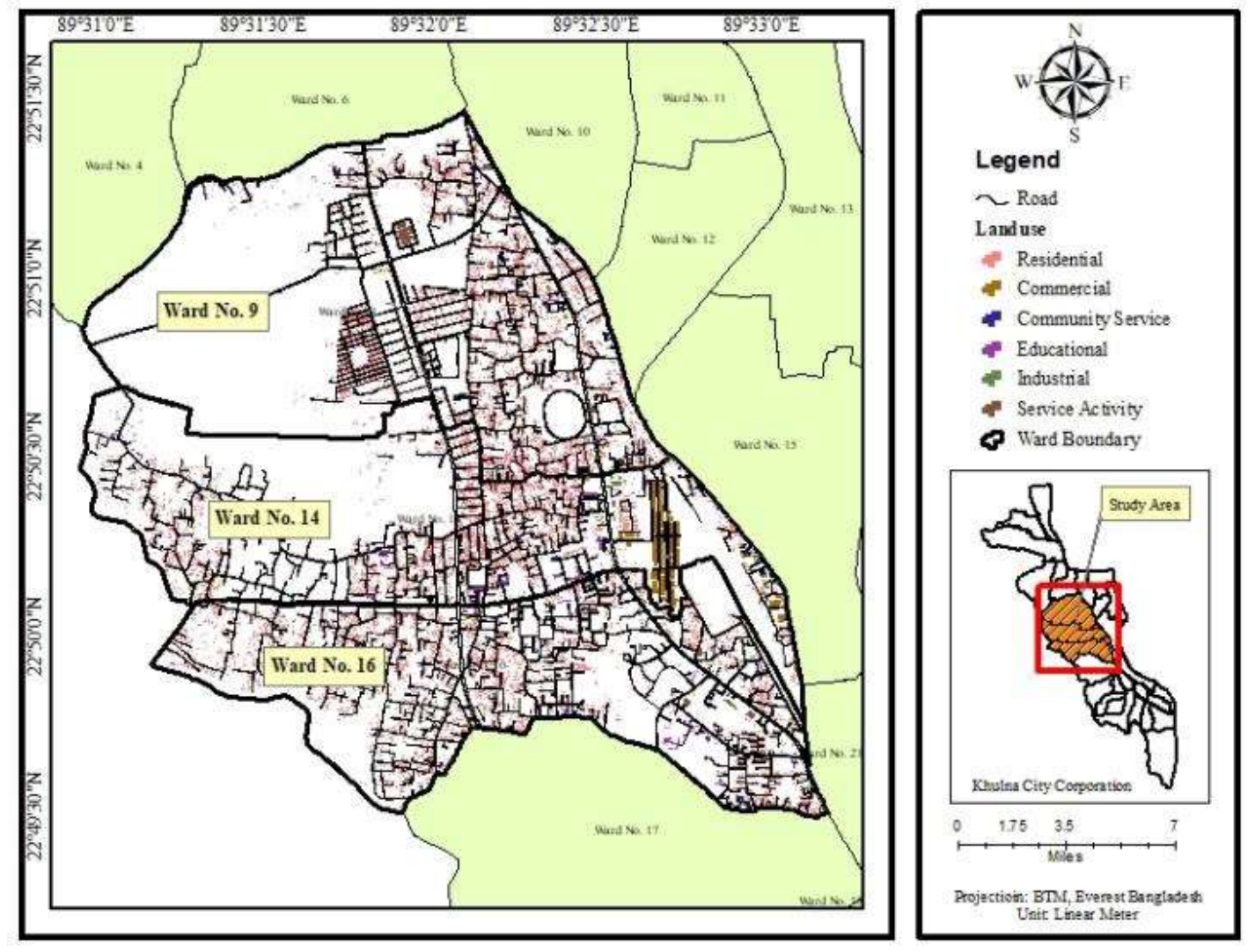

Figure 1. Location map of study area (KCC Ward No. 9, 14, 16). (Source: KCC, 2019) 


\subsection{DATASET PREPARATION}

The study has been conducted by using two satellite images of less than $10 \%$ land and scene cloud coverage, collected from US Geological Survey (USGS). Two satellite images of 2001(march) and 2019(march) were taken to avoid the impact of seasonal temperature variations on the land surface temperature variations in the Landsat images. And due to less possibility of rainfall in Bangladesh during March, the accuracy or acceptability of LST result is higher than other months. The satellites specification utilized in the study was described in Table 1.

Table 1. Satellite Sepcification.

\begin{tabular}{|c|c|c|c|c|c|}
\hline $\begin{array}{c}\text { Satellite/ } \\
\text { Sensor }\end{array}$ & $\begin{array}{c}\text { Pixel } \\
\text { Size }\end{array}$ & Spectral Resolution & Resolution & $\begin{array}{c}\text { Path and } \\
\text { Row }\end{array}$ & Date \\
\hline LANDSAT 5 & 30 & Multispectral (6 Bands) & $30 \mathrm{~m}$ & $138 / 44$ & $17 / 03 / 2001$ \\
\hline LANDSAT 8 & 30 & Multispectral (11 Bands) & $30 \mathrm{~m}$ & $137 / 44$ & $28 / 03 / 2019$ \\
\hline
\end{tabular}

\subsection{LAND USE AND LAND COVER MAP PREPARATION}

In order to make land cover map, image enhancement tool is used to classify and select the area of interest. Contrast Enhancement, Saturation, hue, intensity and Density Slicing etc. are the most used ways to enhance Landsat images. In this study, Landsat images were enhanced by generating composite band combination [16]. The radiometric and atmospheric correction of the Landsat satellite images has been conducted. In this study, the generation of composite band combinations such as natural color composite, true color composite, false color composite etc. are used to identify the land use type in the study area. Blue, green, red and near infrared bands were used for Landsat 5 TM images of 2001 and Landsat 8 OLI images of 2019 to find true color during data processing in Earth Resources Data Analysis System (ERDAS) Imagine 2014.

The land cover type has been classified into five categories (buildup area, vacant land, agricultural land, waterbodies, greeneries) in ArcGIS (geo-spatial planning tool) and EARDAS Imagine 14 to identify the land cover pattern at the study area in the year 2001 and 2019. Then the land cover type change direction during the study period 2001 to 2019 has been analyzed in ArcGIS 10.6 version.

\subsection{ACCURACY ASSESSMENT}

During the same time frame, a comparison was made between the 400 random sampling points and their corresponding point on Google Earth images to verify the LULC classifications [20]. The most likelihood supervised image classification method used for this research is of good accuracy as the validity rates are more than $90 \%$ for the study area.

\subsection{LAND SURFACE TEMPERATURE (LST)}

Land surface temperature has been calculated for the year 2001 and 2019 in the study area by using Landsat $5 \mathrm{TM}$ and Landsat 8 OLI satellite images, respectively. Rahman and Kabir stated the massive increase of population, industrial areas, and alternation of LCT mostly in the Khulna city since the year 2000 [30] for which the study period is chosen between 2001 to 2019. Then LST map has been generated for both year and change in LST have been identified for each ward during the study time. Equation 1-5 were used to estimate the LST [21].

$$
\mathrm{L}_{\lambda}=\mathrm{A}_{\lambda}+\mathrm{M}_{\mathrm{L}} * \mathrm{Q}_{\mathrm{CAL}}
$$

where

$\mathrm{L} \lambda=$ TOA Spectral Radiance $\left(\mathrm{W} /\left(\mathrm{m}^{2} \times \mathrm{sr} \times \mu \mathrm{m}\right)\right)$

$\mathrm{ML}=$ Radiance multiplicative scaling factor for the band 
$\mathrm{AL}=$ Radiance additive scaling factor for the band

$\mathrm{QCAL}=$ the quantized calibrated pixel value in Digital Numbers (DN)

In the second step the TOA spectral radiance ( $\mathrm{L} \lambda)$ values are converted into another variable called AtSatellite Brightness Temperature (TB)

$$
\mathrm{TB}=\frac{\mathrm{k}_{2}}{\ln \frac{\mathrm{k}_{1}}{\mathrm{~L}_{1}+1}}
$$

Where

TB =At-Satellite Brightness Temperature, in Kelvin (K)

$\mathrm{K} 1, \mathrm{~K} 2=$ Thermal conversion constants for the band

Finally, the TOA Brightness Temperature will be converting to land surface temperature values (LST) using the formula.

$$
L S T=[T B /(1+(\lambda * T B / \alpha)) * \ln \varepsilon]
$$

Where

LST $=$ Land Surface Temperature in Kelvin $(\mathrm{K})$

$\lambda=$ the wavelength of emitted radiance

$\alpha=\mathrm{hc} / \mathrm{k}(1.438 \times 10-2 \mathrm{mK})$

$\mathrm{h}=$ Planck constant $(6.626 \times 10-34 \mathrm{~J} \mathrm{~s}-1)$, and $\mathrm{c}=$ velocity of light $(2.998 \times 108 \mathrm{~m} \mathrm{~s}-1)$

$\mathrm{k}=$ Boltzmann constant $(1.38 \times 10-23 \mathrm{~J} \mathrm{~K}-1)$

$\varepsilon=$ surface emissivity, calculated according to equation 4

$\varepsilon=0.004 * P v+0.986$

Where

$\mathrm{Pv}$ is the vegetation proportion calculated following equation 5.

$$
P y=\left[\frac{N D V I-N D V I \min }{N D V I-N D V I \max }\right]^{2}
$$

To obtain the land surface temperature values in Celsius $\left({ }^{\circ} \mathrm{C}\right), 273.15$ was extracted from the initial values $(\mathrm{K})$.

\subsection{NORMALIZED DIFFERENCE VEGETATION INDEX (NDVI)}

The NDVI is calculated using near-Infrared spectral band and Red spectral band of Landsat's multispectral sensor. [21]. The concept of estimating the NDVI is based on the absorption of radiation in the red $(\mathrm{R})$ spectral band and the maximum reflection of radiation in the near-infrared (NIR) spectral band.

$$
N D V I=\frac{N I R \text { Band }-R E D \text { Band }}{\text { NIR Band }+R E D \text { Band }}
$$

NDVI values vary from -1 to +1 , with values close to -1 suggesting lack of vegetation and values close to +1 indicating dense vegetation.

\subsection{NORMALIZED DIFFERENCE BUILDUP INDEX (NDBI)}

Built-up Index (BU), Normalized Difference Built-up Index (NDBI), Index based Built-up Index (IBI) etc. are used to analyze the built-up area. In this study, NDBI [12] is used to detect the built-up area in the study area.

$$
N D B I=\frac{S W I R-N I R}{S W I R+N I R}
$$


NDBI values vary from -1 to +1 , with values close to -1 suggests no built up area and values close to + 1 indicates the dense built-up area.

\subsection{NORMALIZED DIFFERENCE MOISTURE INDEX (NDMI)}

NDMI is used for the analysis of water bodies in any area. The index uses remote sensing images with Green and Near infrared bands. NDMI can efficiently enhance water information in most cases [22]. The result of NDMI indicates the intensity of waterbodies in the area and illustrates the presence of moisture in soil [29]. The higher value indicates higher intensity of waterbodies and the lower NDMI value indicates absence of waterbodies.

$$
N D M I=\frac{N I R-S W I R}{N I R+S W I R}
$$

NDMI values vary from -1 to +1 , with values close to -1 suggests lack of waterbodies and values close to +1 indicates presence of large waterbodies.

With the calculated values of NDVI, NDMI and NDBI for both years, the NDVI map, NDMI map and NDBI map were generated and then the change of these indexes in each ward during the study period has been identified. Linear regression analysis has been conducted among LST and NDVI, LST and NDWI, LST and NDBI to see which type of land use pattern is mostly responsible for the change of LST in the study area.

\subsection{RELATIONSHIP BETWEEN LST AND LAND COVER CHANGE}

Several Studies $[17,18,23,24]$ have shown that quantifying the LST's effects and spatial patterns involves a clear understanding of the LST's relationship with different types of land cover. These studies only explained the change in surface temperature because of the vegetation land cover transformation. In this study the change of surface temperature due to all types of land cover transformation and their influences has been analyzed. The study extracted the average, maximum and minimum LST values of the five types of land cover in the year 2001 and 2019 and identified the average LST change with change rate during the study period. The study also explored the change of average LST in different land cover, before and after the land cover transformation. The overall study procedure followed in this study is visualized through a methodological framework in Figure 2. 


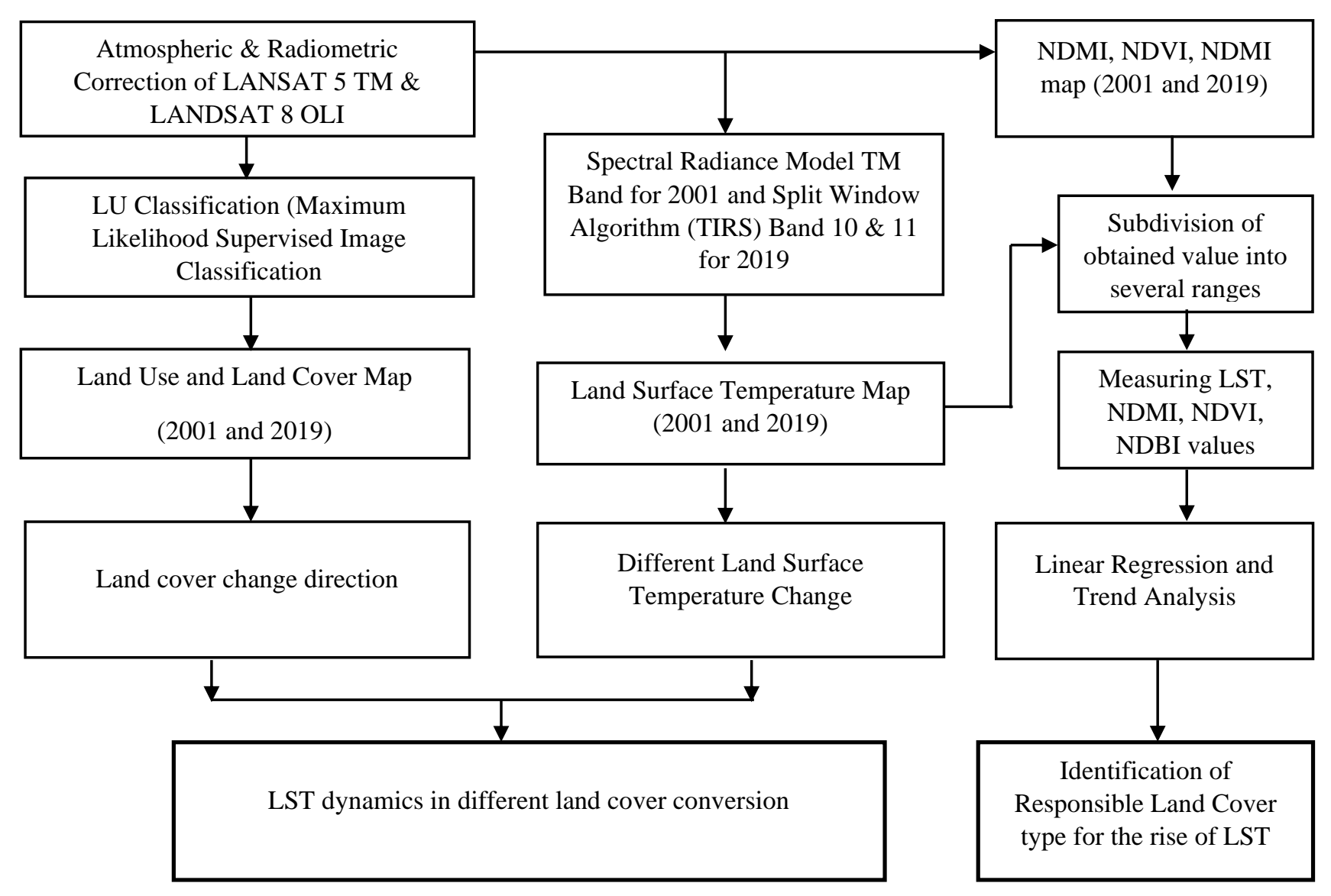

Figure 2. Methodological framework of the study

\subsection{ANALYSIS AND INTERPRETATION}

\subsection{LAND USE AND LAND COVER (LULC) PATTERN CHANGE ANALYSIS}

Increase of population and human activities, either on a large scale or small scale are continuously reducing the waterbody, vegetative cover, vacant land, and agricultural land cover of the earth's surface. GIS based satellite image classification in EARDAS Imagine 2014 for the year 2001 and 2019 in Figure 3 shows that the study area has faced a huge amount of land cover transformation in the last 20 years. The area of each land cover type between 2001 and 2019 for every ward was calculated through maximum likelihood image classification and presented in Table 3. The positive sign in Table 3 indicates the increase of land cover percentage while negative sign indicates the decrease of land cover areas. Table 3 shows that there was a drastic and rapid transformation of waterbody at Mujgunni KCC Ward No 9. Approximately 103.76 acres of waterbodies were transformed into vacant land and buildup area and 229.4 acres of buildup area was increased at Mujgunni. Introduction of Mujgunni Residential Area has influenced mostly in this rapid increase of the buildup areas at Ward No 9. Table 3 shows the highest percentage $(54.33 \%$ ) of LULC at ward 9, then $35.65 \%$ in ward 14 and $27.44 \%$ at ward 16. 

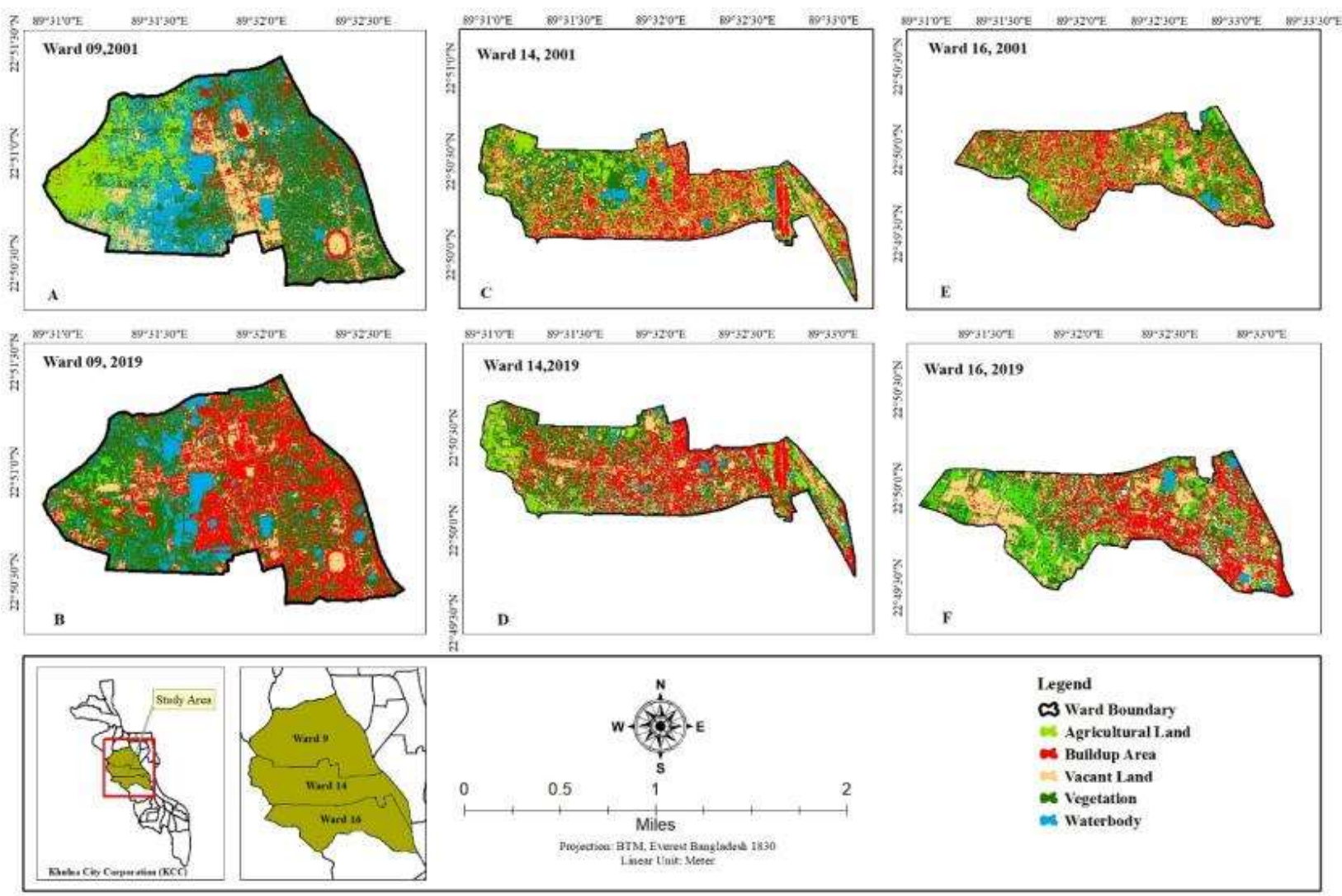

Figure 3. Land Use and Land Cover map of KCC (A) Ward No 9 in 2001 (B) Ward No 9 in 2019 (C) Ward No 14 in 2001 (D) Ward No 14 in 2019 (E) Ward No 16 in 2001 and (F) Ward No 16 in 2019.

Table 3. Land cover area in the year 2001 and 2019 in each ward (Unit: Percentage)

\begin{tabular}{|l|c|c|c|c|c|c|c|c|c|}
\hline \multirow{2}{*}{$\begin{array}{c}\text { Land Cover } \\
\text { Type }\end{array}$} & \multicolumn{3}{|c|}{ Ward N 9 } & \multicolumn{3}{c|}{ Ward No. 14 } & \multicolumn{3}{c|}{ Ward No. 16 } \\
\cline { 2 - 9 } & $\mathbf{2 0 0 1}$ & $\mathbf{2 0 1 9}$ & Change & $\mathbf{2 0 0 1}$ & $\mathbf{2 0 1 9}$ & Change & 2001 & 2019 & Change \\
\hline Agricultural & $14.89 \%$ & $4.11 \%$ & $\begin{array}{c}- \\
10.78 \%\end{array}$ & $23.17 \%$ & $13.65 \%$ & $-9.52 \%$ & $29.02 \%$ & $15.30 \%$ & - \\
& & & & & & & & $13.72 \%$ \\
\hline $\begin{array}{l}\text { Build up } \\
\text { Area }\end{array}$ & $7.71 \%$ & $34.88 \%$ & $27.17 \%$ & $27.31 \%$ & $45.14 \%$ & $17.83 \%$ & $29.97 \%$ & $34.70 \%$ & $4.73 \%$ \\
\hline Vacant Land & $16.18 \%$ & $12.83 \%$ & $-3.35 \%$ & $15.52 \%$ & $14.68 \%$ & $-0.83 \%$ & $18.44 \%$ & $21.99 \%$ & $3.54 \%$ \\
\hline Vegetation & $36.56 \%$ & $35.83 \%$ & $-0.74 \%$ & $31.20 \%$ & $25.41 \%$ & $-5.79 \%$ & $21.65 \%$ & $26.40 \%$ & $4.76 \%$ \\
\hline Waterbody & $24.65 \%$ & $12.37 \%$ & - & $2.80 \%$ & $1.13 \%$ & $-1.68 \%$ & $0.92 \%$ & $1.61 \%$ & $0.70 \%$ \\
\hline Total & $\mathbf{1 0 0 \%}$ & $\mathbf{1 0 0 \%}$ & $\mathbf{5 4 . 3 3 \%}$ & $\mathbf{1 0 0 \%}$ & $\mathbf{1 0 0 \%}$ & $\mathbf{3 5 . 6 5 \%}$ & $\mathbf{1 0 0 \%}$ & $\mathbf{1 0 0 \%}$ & $\mathbf{2 7 . 4 4 \%}$ \\
\hline
\end{tabular}

Figure 3C, 3D and Table 3 shows that about $17.83 \%$ of buildup area has increased and 5.79\% of vegetation and $1.68 \%$ of waterbody area has been decreased at $\mathrm{KCC}$ ward no 14. Table 3 illustrates that buildup area was increased mostly in Ward No 9 by $27.17 \%$ and due to the filling of waterbodies and wetlands, waterbody land cover area percentage was declined by $12.29 \%$ during the study period. Although the rate of Land Use Transformation (LUT) was higher in KCC Ward no 9 and 14, it is noticed less in case of ward no 16. From the field survey it is found that, due to the establishment of a residential area in Ward No 9, many houses and building were built in there. As a result, people built many infrastructures in there for which they filled up waterbodies, wetlands, and agricultural lands. GIS based satellite image classification in Table 3 and Figure 3E and 3F shows that only $4.73 \%$ (28.52 acres) of buildup area has increased, $0.70 \%$ (4.20 acres) of waterbody area and $4.76 \%$ (28.7 acres) of vegetated area was also increased in ward 16. But about $13.72 \%$ ( 72.8 acres) of agricultural land has been decreased during the study period. 
The land use and land cover (LULC) change direction analysis in ArcGIS shows a remarkable change of LULC in 20 years. Figure 4 shows that about 110.73acres (5.24\%) of waterbodies, 227.27acres (10.75\%) of agricultural land has been transformed into build up areas. The land cover change direction analysis illustrated in Figure 4 shows that waterbody and agricultural land cover were worst affected in the study area. Due to the high percentage of agricultural and waterbody land cover area in the study area, these two land cover types have become transformed mostly. Moreover, many waterbodies are still being filled for further construction of buildings in the future. As a result of urban expansion and growth of population, vegetation, waterbodies, agricultural land, and vacant land surfaces exposed.

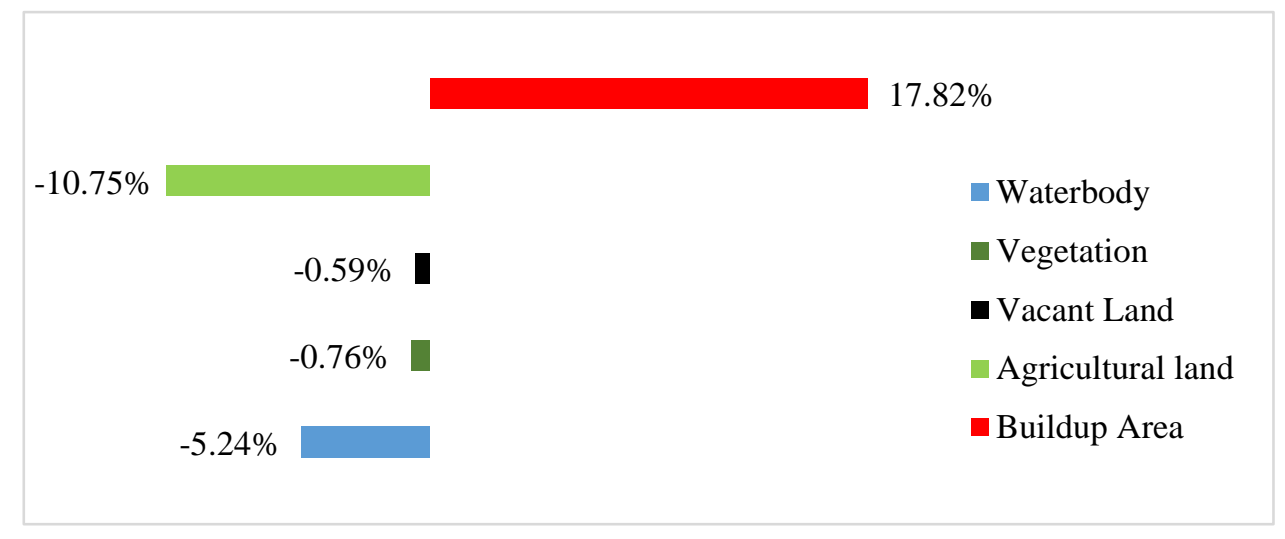

Figure 4. LULC change direction analysis between 2001 to 2019 at study area.

\subsection{LST DYNAMICS IN RESPONSE TO NDMI}

The value of NDMI lies between -1 to 0 to +1 . Higher value NDMI indicates the higher density of water surface and lower density of buildup area. Using equation 8, NDMI profile of the study area in both study period was calculated and presented in Figure 5.
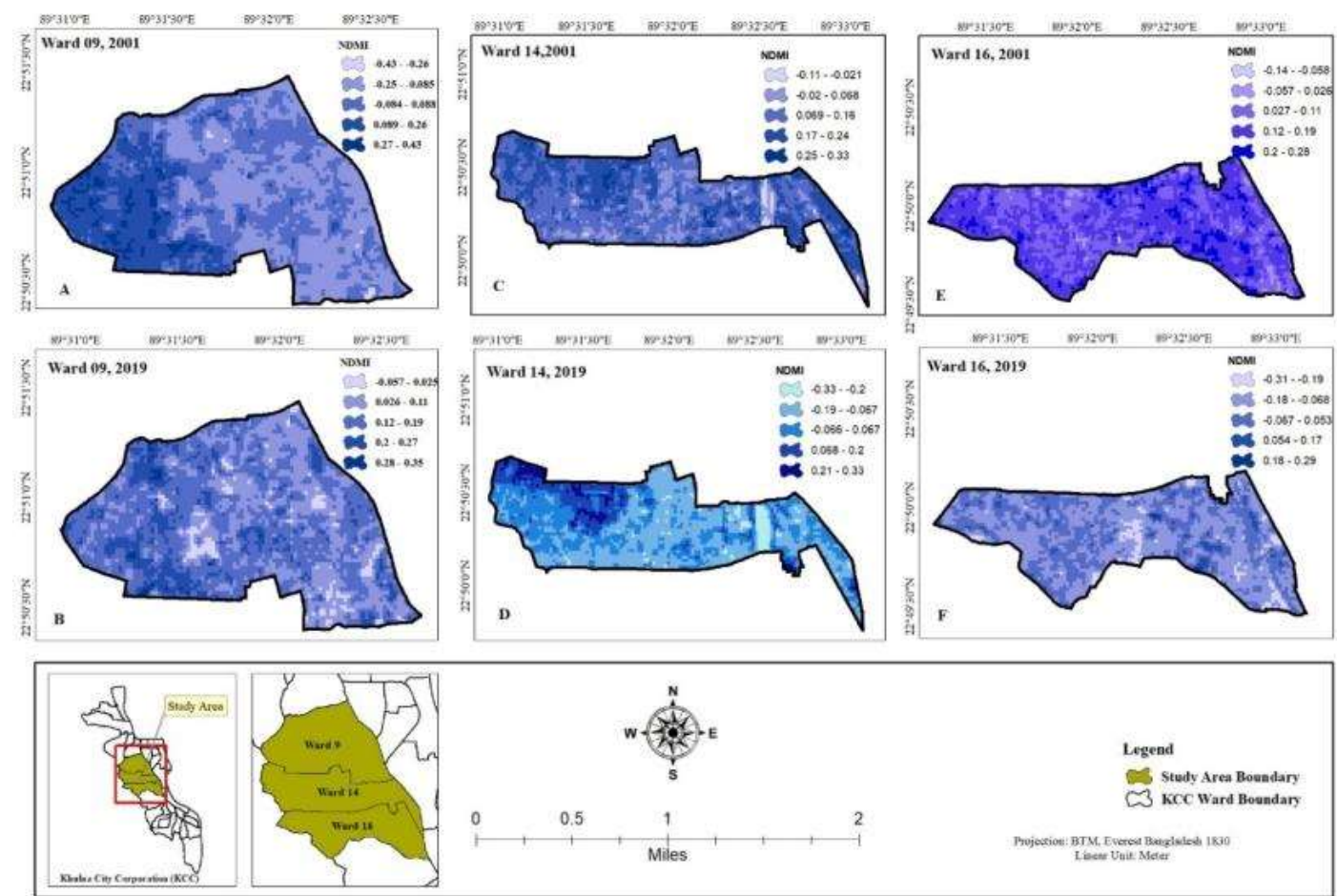

Figure 5. Normalized Difference Moisture Index map of KCC (A) Ward No 9 in 2001 (B) Ward No 9 in 2019 (C) Ward No 14 in 2001 (D) Ward No 14 in 2019 (E) Ward No 16 in 2001 and (F) Ward No 16 in 2019. 
With the growth of population and because of urbanization, 5.24\% (110.73 acres) of waterbodies (Figure 4) has been transformed across the study and resulted in the decrease of NDMI value (Figure 5). The higher value of NDMI is decreased from 0.43 to 0.33 in 9 No Ward (Figure 5A, B) and increased from 0.29 to 0.27 in 16 No Ward (Figure 5E, F). But the percentage of dense water cover areas across the study area has reduced.

As in Ward No 16, vegetation and waterbodies area has increased (4.76\% and $0.70 \%$ respectively in Table 3 ) and buildup area increasing rate was low, the total percentage of areas with higher NDMI value was increased in 2019 (Figure 5E, 5F). Though the higher value of NDMI at 14 No Ward has increased but the percentage of buildup area has increased (Figure 2C, D). Therefore, it can be concluded that NDMI has been decreasing and the percentage of areas with lower NDMI value are increasing day by day across the study area.

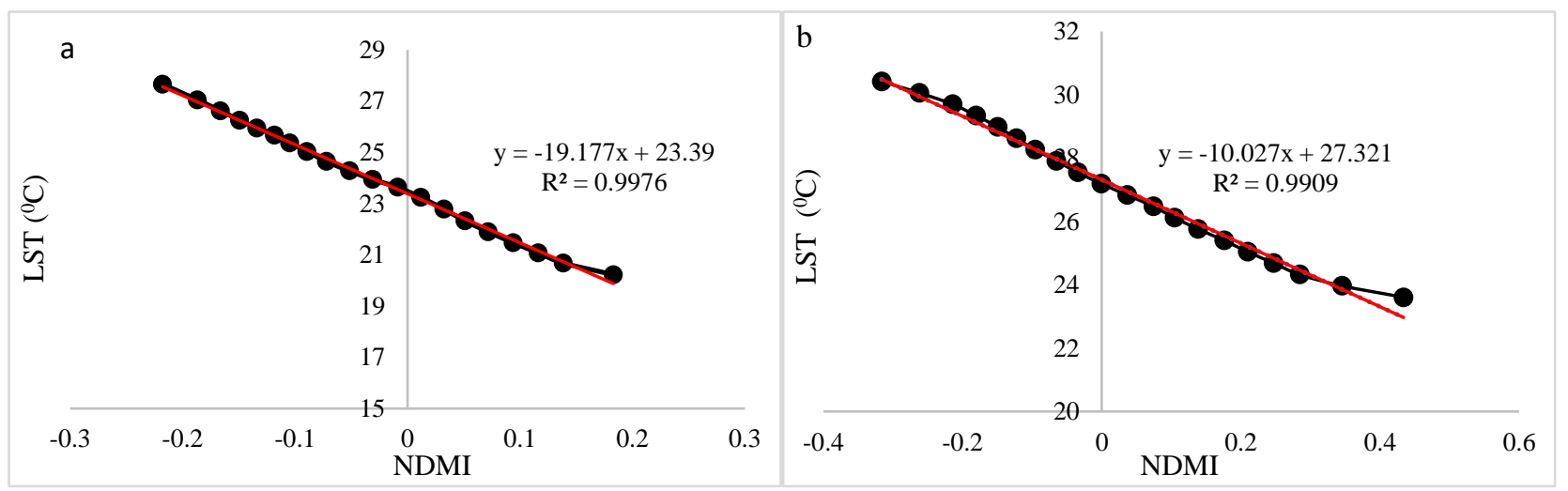

Figure 6. Linear correlation between LST change in response to NDMI value change in the year (A) 2001 and (B) 2019.

From the regression analysis between LST and NDMI in Figure 6 shows an increasing trend of LST with the decrease of NDMI value. The regression analysis for the year 2001 in Figure 6 represents the negative relationship between LST and NDMI values i.e. decrease of waterbodies influences in the increase of surface temperature. The value of coefficient of determination (R2) was calculated 0.9976 for the year 2001 and 0.9909 for the year 2019 which indicates the significant relationship between NDMI and LST. Figure 6 states that the surface temperature increased during the study period because of the reduction of the total amount of waterbodies in the study area.

\subsection{LST DYNAMICS IN RESPONSE TO NDVI}

The values of NDVI vary between -1 to +1 . The values of NDVI more than 0.3 indicates the healthy vegetation, the value from 0.01 to 0.02 and from 0.02 to 0.03 indicates non vegetated area and unhealthy vegetation [29]. The NDVI values for the study area was calculated by using equation 6 and illustrated in Figure 7. Figure 7 visualizes the declination of the healthy vegetation and increase of the unhealthy vegetation area in every ward. NDVI change analysis shows that the percentage of the unhealthy vegetation area and non-vegetated area has been increased at Mujgunni mostly. Where the total amount of healthy vegetation areas declined mostly at ward no 14 showed in Figure 7C, 7D. That is why the average LST increased mostly at ward no 9 and ward no 14 mostly which presented in Figure 7. 

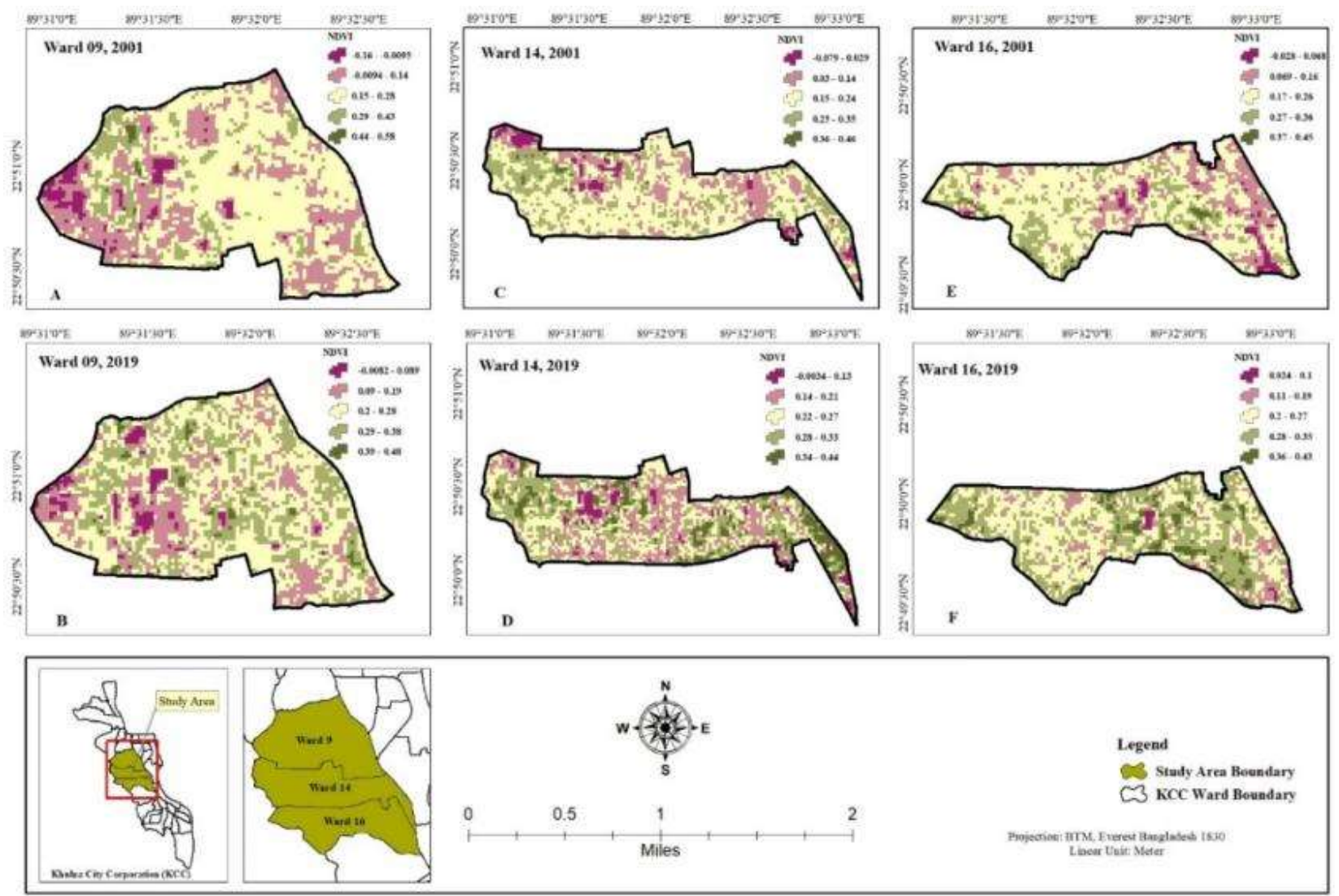

Figure 7. Normalized Difference Vegetation Index map of KCC (A) Ward No 9 in 2001 (B) Ward No 9 in 2019 (C) Ward No 14 in 2001 (D) Ward No 14 in 2019 (E) Ward No 16 in 2001 and (F) Ward No 16 in 2019.

In 2001, NDVI range was between -0.0082 to $+0.48,-0.0034$ to +0.44 and $-0.024-0.43$ at ward no 9,14 and 16, respectively. But the value has been changed and showed a positive change condition in 2019 though, the average NDVI value declined from 0.25 to 0.1837 . Transformation of vegetation areas and agricultural land is responsible for the increase of LST in the study area. If the deforestation and cut of urban trees are not stopped, then this situation will continue to be worse day by day.

The linear regression trend analysis of NDVI (Figure 8) for the year 2001 and 2019 shows the strong negative correlation between LST and NDVI value. Figure 8 indicates that surface temperature decreases with the increase of NDVI values that means with the increase of dense vegetation areas. The coefficient of determination value found 0.986 for the year 2001 and 0.9955 for the year 2019 and both indicates the strong or significant response of surface temperature with the change of NDVI values.

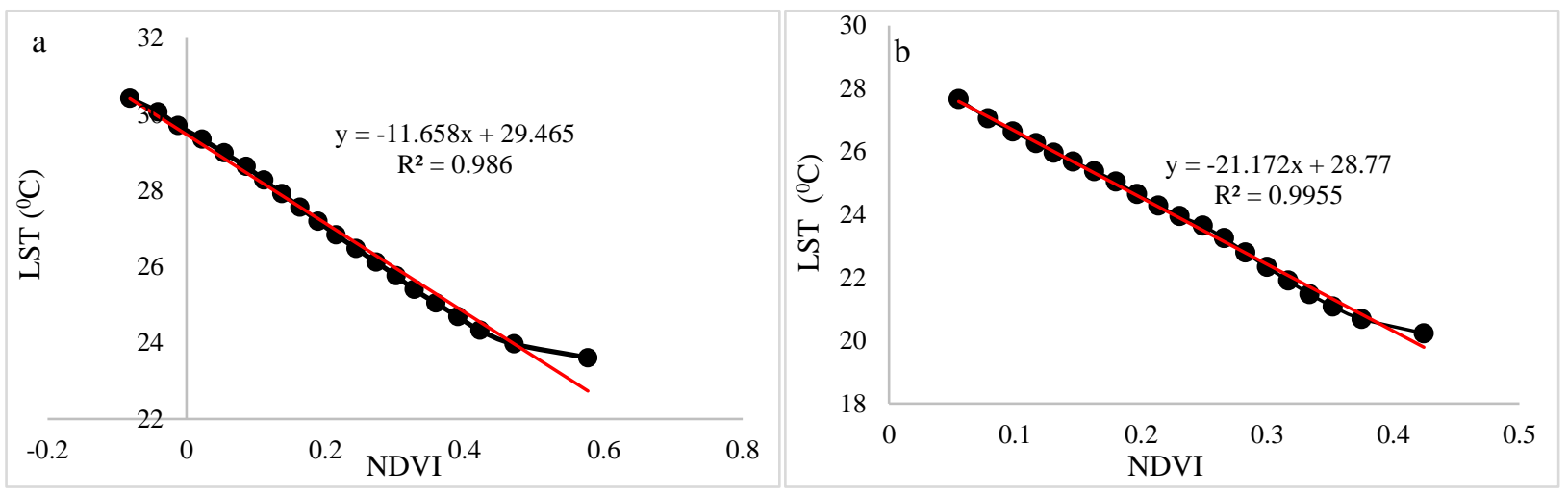

Figure 8. Linear correlation between LST change in response to NDVI value change in the year (A) 2001 and (B) 2019. (Source: Author, 2020) 


\subsection{LST DYNAMICS IN RESPONSE TO NDBI}

Increase of buildup areas by 376.59 acres over the study period has increased the NDBI value across the study area. NDBI have indices value ranges from -1 to 1 . The higher value of NDBI has increased from 0.056 to 0.43 at ward no 9 (Figure 9A, B), 0.10 to 0.33 at ward no 14 (Figure 9 C, D) and 0.14 to 0.30 at ward no 16 (Figure $9 \mathrm{E}, \mathrm{F}$ ). The analysis shows that NDBI has increased 8 times at ward no 9, 3 times at ward 14 and 2 times at ward 16.
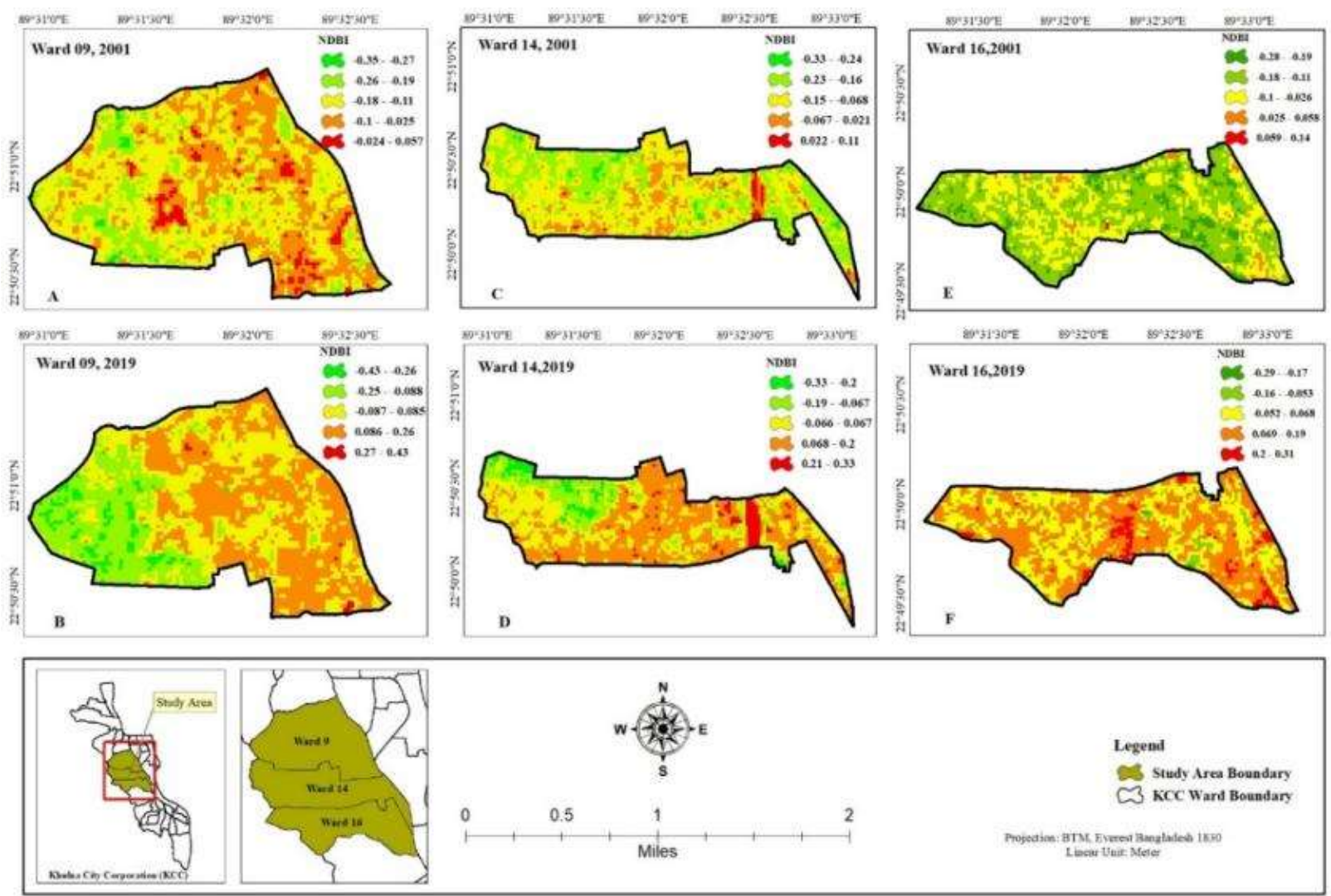

Figure 9 Normalized Difference Buildup Index map of KCC (A) Ward No 9 in 2001 (B) Ward No 9 in 2019 (C) Ward No 14 in 2001 (D) Ward No 14 in 2019 (E) Ward No 16 in 2001 and (F) Ward No 16 in 2019.

Figure 9 visualizes a huge change of NDBI during the year 2001 to 2019 across the study area.
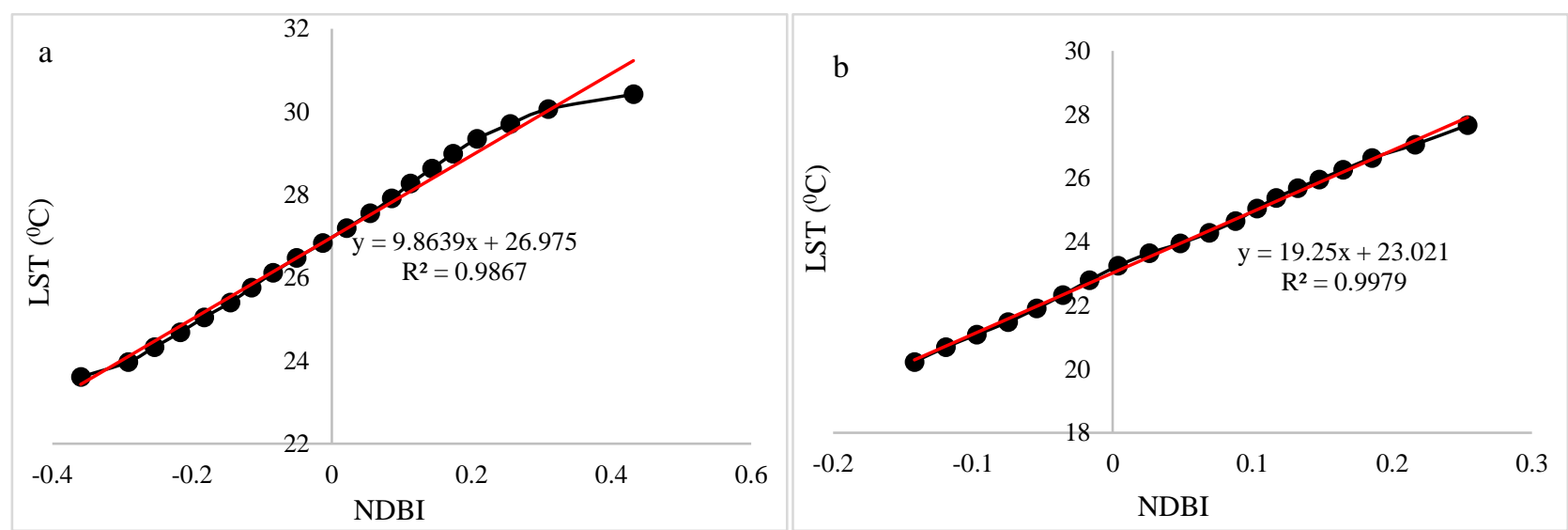

Figure 10. Linear correlation between LST change in response to NDBI value change in the year (A) 2001 and (B) 2019. 
As the total amount of increased buildup area was most at Mujgunni, the value of NDBI is changed mostly in this area than other wards. In 2001 the NDBI range was between -0.35 and 0.14 across the study area, which is gradually increased to between -0.43 to +0.43 (Figure 9). The higher value increased about 3 times and the lower value of NDBI has decreased very slightly. Therefore, it can be concluded that the NDBI is increasing at a tremendous rate in KCC areas over the time.

The linear regression between LST and NDBI and the trend analysis in Figure 10 represents the rise of LST with the increase of NDBI value over the time. The value of coefficient of determination, $\mathrm{R}^{2}=0.9867$ in 2001(Figure $10 \mathrm{~A}$ ) describes the strong responsive relationship between LST and NDBI. The transformation of other land cover types in buildup areas has influenced to make the relationship stronger in the year 2019. The value of $\mathrm{R}^{2}=0.9979$ in the year 2019 (Figure $10 \mathrm{~B}$ ) indicates the strongly significant relationship between LST and NDBI. The coefficient of determination in the Figure 6, 8 and 10 suggests that LST responded mostly with the change of NDBI value (as the relationship between NDBI and LST found most significant) i.e. the increase of buildup area is mostly responsible for the increase of surface temperature in the study area during the study time period.

\subsection{LAND SURFACE TEMPERATURE(LST) CHANGE}

The surface temperature change analysis shows that the average land surface temperature across the study area has increased by $3.43^{\circ} \mathrm{C}$ during the study period at the rate of $1.714^{\circ} \mathrm{C} /$ decade. Table 4 shows the increase of the minimum, maximum and average temperature of different land cover during the study period. The derived LST value range for each ward during the study period illustrated in Figure 11 shows the clear increase of LST of each ward. The lowest LST increased by $1.71^{\circ} \mathrm{C}, 1.85^{\circ} \mathrm{C}$ and $0.74^{\circ} \mathrm{C}$ at Ward No 9, 14 and 16, respectively. The reason for this higher increase of LST value at ward 9 and 14 is that the buildup area has increased mostly at these wards. LULC change direction analysis in Figure 4 demonstrated the declination of a huge percentage of ecofriendly land cover types such as agricultural land, waterbodies, and vegetation land cover areas during the study period. This has adversely affected the environment of the study area and influenced in the alternation of surface heat retention capacity. As the buildup area was increased and the total amount of ecofriendly land cover types was decreased, the percentage of area with higher LST value has increased. Such increase of surface temperature will reduce the fertility of agricultural land and will increase soil salinity of the study area.

Table 4. Observed LST in different land cover in the year 2001 and 2019

\begin{tabular}{|l|c|c|c|c|c|c|}
\hline \multirow{2}{*}{\multicolumn{1}{|c|}{ Land use }} & \multicolumn{3}{c|}{ LST in 2001 $\left({ }^{\mathbf{0}} \mathbf{C}\right)$} & \multicolumn{3}{c|}{ LST in 2019 $\left({ }^{\mathbf{O}} \mathbf{C}\right)$} \\
\cline { 2 - 7 } & Minimum & Maximum & Average & Minimum & Maximum & Average \\
\hline Buildup Area & 25.40 & 27.52 & 26.24 & 28.35 & 31.24 & 30.83 \\
\hline Vacant Land & 24.55 & 26.67 & 25.80 & 26.19 & 30.42 & 29.95 \\
\hline Agricultural Land & 23.68 & 27.10 & 24.85 & 25.45 & 28.18 & 27.39 \\
\hline Vegetation Land & 23.68 & 26.67 & 24.83 & 25.83 & 30.01 & 28.23 \\
\hline Waterbody & 23.68 & 27.93 & 26.16 & 25.40 & 30.42 & 28.88 \\
\hline
\end{tabular}

The derived LST value range (higher value and lower value) in Figure 11A, 11C, 11D shows that the range of observed LST in each ward was different in 2001 and the variation is also remained in the year 2019. As, the total amount of vegetation and waterbody areas has increased at ward 16 (Table 3), the higher value of LST in this ward has decreased $\left(28.76^{\circ} \mathrm{C}\right.$ to $\left.28.70^{\circ} \mathrm{C}\right)$ (Figure $\left.11 \mathrm{E}, \mathrm{F}\right)$. The average LST increased from $25.80^{\circ} \mathrm{C}$ to $27.15^{\circ} \mathrm{C}$ in Ward No $9,26.84^{\circ} \mathrm{C}$ to $27.23^{\circ} \mathrm{C}$ in Ward No 14 and $26.87^{\circ} \mathrm{C}$ to $27.12^{\circ} \mathrm{C}$ in Ward No 16. The total amount of areas with higher LST value has increased mostly at ward no 9 (Figure $11 \mathrm{C}, \mathrm{D}$ ) and at ward 16 (Figure $11 \mathrm{E}, \mathrm{F}$ ). Though the distance between these wards is very less but the range of LST value varied in these three wards. Figure 3 and Figure 11 reveals that LST has responded variedly in each ward as the LULC change also varied in each ward. 

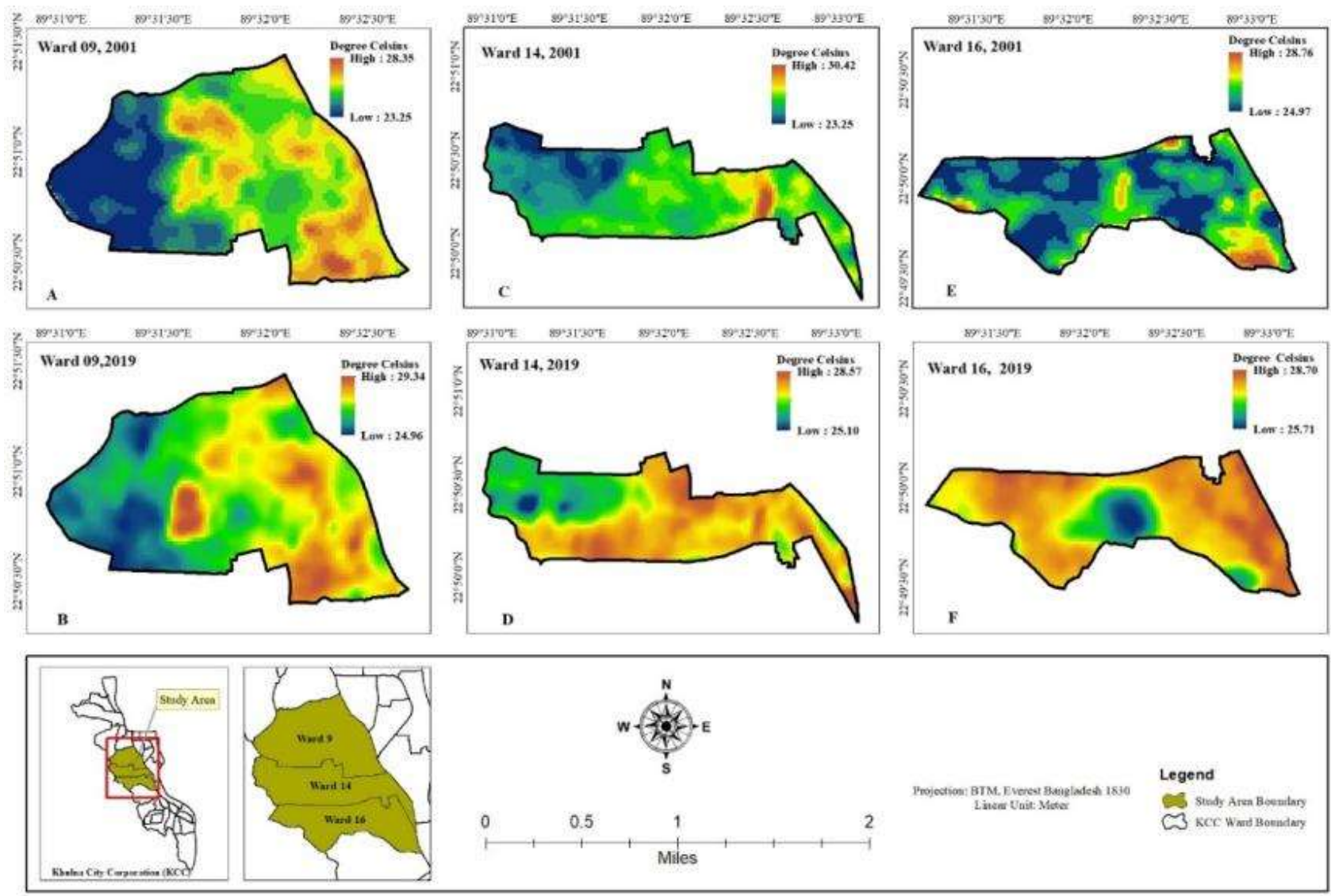

Figure 11. Land Surface Temperature map of KCC (A) Ward No 9 in 2001 (B) Ward No 9 in 2019 (C) Ward No 14 in 2001 (D) Ward No 14 in 2019 (E) Ward No 16 in 2001 and (F) Ward No 16 in 2019.

Table 5 shows that average LST of buildup areas increased mostly by $4.59^{\circ} \mathrm{C}$ and the average LST of vacant land, waterbody and agricultural land cover increased from $25.80^{\circ} \mathrm{C}$ to $29.95^{\circ} \mathrm{C}, 26.16^{\circ} \mathrm{C}$ to $28.23^{\circ} \mathrm{C}$ and $24.85^{\circ} \mathrm{C}$ to $27.39^{\circ} \mathrm{C}$ respectively (Table 4). Destruction of waterbodies and the rise of atmospheric temperature has influenced in the increase of water surface temperature. The rise of minimum, maximum and average LST in buildup areas land cover during the study time period and regression analysis between NDVI and LST, NDMI and LST, NDBI and LST demonstrated that increase of buildup area is mostly responsible for the increase of Land Surface Temperature in the study area.

Table 5. Nature of average surface temperature increase in different land cover during the study period

\begin{tabular}{|l|c|c|}
\hline Land Cover Type & Increased LST $\left({ }^{\mathbf{0}} \mathbf{C}\right)$ & Avg. LST increasing rate $\left({ }^{\mathbf{0}} \mathbf{C} /\right.$ year $)$ \\
\hline Buildup Area & 4.59 & 0.229 \\
\hline Vacant Land & 4.15 & 0.2075 \\
\hline Agricultural Land & 2.54 & 0.127 \\
\hline Vegetation Land & 3.4 & 0.17 \\
\hline Waterbody & 2.72 & 0.136 \\
\hline
\end{tabular}

\subsection{LST DYNAMICS IN RESPONSE TO LULC TRANSFORMATION}

Surface temperature changes during the study year in different land cover types was determined across the study area. Increase of LST has been observed in all types of land cover transformation except transformation of LC into waterbodies. Surface temperature has increased mostly due to the increase in buildup areas (Table 6). Conversion of waterbody into build up area has increased surface temperature mostly by $3.23^{\circ} \mathrm{C}$ with a rate of $0.161^{\circ} \mathrm{C} /$ year (Table 6). 
Table 6. Surface temperature change in response to land cover change in the study area.

\begin{tabular}{|l|c|c|c|c|}
\hline $\begin{array}{l}\text { Land Cover } \\
\text { Transformation }\end{array}$ & $\begin{array}{c}\text { Avg. Temp in } \\
\mathbf{2 0 0 1}\left({ }^{\mathbf{0}} \mathbf{C}\right)\end{array}$ & $\begin{array}{c}\text { Avg. Temp in } \\
\mathbf{2 0 1 9}\left({ }^{\mathbf{}} \mathbf{C}\right)\end{array}$ & $\begin{array}{c}\text { Avg. LST } \\
\text { Change }\left({ }^{\mathbf{0}} \mathbf{C}\right)\end{array}$ & $\begin{array}{c}\text { Increasing Rate } \\
\left({ }^{\mathbf{0}} \mathbf{C} / \text { year }\right)\end{array}$ \\
\hline Waterbody to Buildup & 25.91 & 29.14 & 3.23 & 0.161 \\
\hline Waterbody to Vacant & 24.83 & 27.88 & 3.05 & 0.153 \\
\hline Waterbody to Agricultural & 25.19 & 27.01 & 1.82 & 0.091 \\
\hline Vegetation to Buildup & 26.67 & 28.95 & 2.28 & 0.114 \\
\hline Vegetation to Agricultural & 24.37 & 26.49 & 2.12 & 0.106 \\
\hline Vegetation to Vacant & 25.57 & 27.18 & 1.61 & 0.081 \\
\hline Agricultural to Buildup & 27.03 & 30.06 & 3.03 & 0.151 \\
\hline Agricultural to Vacant & 24.54 & 27.40 & 2.84 & 0.142 \\
\hline Agricultural to Waterbody & 26.01 & 25.55 & -0.46 & -0.023 \\
\hline Vacant to Buildup & 26.89 & 29.93 & 3.04 & 0.152 \\
\hline Vacant to waterbody & 26.23 & 25.84 & -0.39 & -0.020 \\
\hline Vacant to Agricultural & 25.88 & 27.91 & 2.03 & 0.102 \\
\hline
\end{tabular}

The analysis shows that the surface temperature has changed mostly due to the conversion of vegetation, agricultural land and waterbody into buildup areas which is also found in the NDBI and NDMI value change direction analysis and their trend analysis. Transformation of vacant land and agricultural land into waterbodies has decreased the surface temperature by $0.39^{\circ} \mathrm{C}$ and $0.46^{\circ} \mathrm{C}$, respectively. The analysis shows that the surface temperature has risen in response to various changes in land use and land cover in different areas of the study area. The overall land cover transformation rate across the study area is indicating a huge increase of surface temperature in the future.

\subsection{CONCLUSION}

The study reveals a drastic land use and land cover transformation of agricultural land and waterbodies in the study area. Unplanned urbanization has resulted in the increase of 376.59 acres $(17.82 \%)$ of buildup area and destruction of 227.27 acres $(10.75 \%)$ of agricultural land and 110.73 acres (5.24\%) of waterbodies in the study area in just 18 years. This high increasing rate of buildup area has influenced in the unexpected change of NDMI, NDVI and NDBI indices values. Though the three wards are located side by side, but the LST and NDMI, NDVI, NDBI indices values have changed differently as the land cover transformation type varied in each ward. The Most distinct observation was that the surface temperature has increased mostly in those areas where waterbodies and vacant land has transformed into buildup areas. Overall study demonstrates that the land covers are not changed in a planned way in everywhere in Khulna city. As a result, environmental changes in microlevel are taking place very subtly such as the rapid increase of surface temperature, atmospheric temperature, and changes in landscape. This unplanned land cover type conversion into buildup areas has increased the average LST by $3.43^{\circ} \mathrm{C}$ with the rate of $1.714^{\circ} \mathrm{C} /$ decade across the study area. Such land cover change at micro level are causing many other adverse reactions to its environment, which in the macro level such as city level is often not well realized. The valuation of environmental change at the micro level through this study will help to aware people about the significance of planned land use change and researcher to focus on the root level land use dynamics to mitigate the adverse effects of it on the environment.

\subsection{ACKNOWLEDGEMENT}

The authors gratefully acknowledged the EarthExplorer -USGS as the source of satellite images and also thankful to Professor Mustafa Saroar, KUET for giving the theoretical knowledge. Mr. Saif Siam, Mr. Fazle Rabbi and Fahmida Yeasmin Sami helped in data collection. Anonymous reviewers are also 
acknowledged for their crucial comments that have helped the authors to improve the manuscript substantially. The authors are also grateful to the editorial team.

\section{REFERENCES}

[1] U. Shahzad, 2015. Global Warming: Causes, Effects and Solutions. Durreesamin Journal, Vol. 1, No. 4.

[2] M. N. Haque, M. A. Mamun, M. M. Saroar and T. K. Roy, 2019. Applical 'tion of "DPSIR" Framework to Assess the Status and Role of Blue Ecosystem Services (BES) in Khulna City. Journal of Engineering Science (JES), Vol. 10, No. 2, pp. 49-60.

[3] P. K. Srivastava, T. J. Majumdar and A. K. Bhattacharya, 2010. Study of land surface temperature and spectral emissivity using multi-sensor satellite data. Journal of Earth System Science, Vol. 119, pp. 67-74, 9.

[4] P. Dash, F.-M. Göttsche, F.-S. Olesen and H. Olesen, 2002. Land surface temperature and emissivity estimation from passive sensor data: Theory and practice-current trends. International Journal of Remote Sensing, Vol. 23, No. 13, pp. 2563-2594.

[5] J. Cristóbal, J. C. Jiménez-Muñoz, J. A. Sobrino, M. Ninyerola and X. Pons, 2009. Improvements in land surface temperature retrieval from the Landsat series thermal band using water vapor and air temperature. Journal of Geophysical Research, Vol. 114, pp. 103-129.

[6] A. Gillespie, S. Rokugawa, G. T. Matsuna, J. S. Cothern, S. Hook and A. B. Kahle, 1998. A temperature and emissivity separation algorithm for Advanced Spaceborne Thermal Emission and Reflection Radiometer (ASTER) images. IEEE Transactions on Geoscience and Remote Sensing, Vol. 36, No. 4, pp. 1113-1126.

[7] Z. Qin, A. Karnieli and P. Berliner, 2001. A mono-window algorithm for retrieving land surface temperature from Landsat TM data and its application to the Israel-Egypt border region. International Journal of Remote Sensing, Vol. 22, No. 18, pp. 3719-3746.

[8] F. S. Kiran and B. U. Joshi, 2019. Estimation of variables explaining urbanization concomitant with land-use change: a spatial approach. International Journal of Remote Sensing, Vol. 34, No. 3, pp. 824-847.

[9] A. Sánchez-Lugo, P. Berrisford, C. Morice and A. Argüez, 2018. Temperature [in "State of the Climate in 2017"]. Bulletin of the American Meteorological Society, Vol. 99, No. 8.

[10] S. Shahid, 2010. Recent trends in the climate of Bangladesh. Climate Research, Vol. 42, No. 3, pp. 185-193.

[11] M. A. Fattah, S. R. Morshed, M. N. Haque and S. Rahman, 2020. Land Use Changes and Its Impact on Environment: A Case Study on Urban Area in Khulna, Bangladesh. International Conference on Civil Engineering for Sustainable Development, Khulna, 2020.

[12] K. V. Singh, R. Setia, S. Sahoo, A. Prasad and B. Pateriya, 2015. Evaluation of NDWI and MNDWI for assessment of waterlogging by integrating digital elevation model and groundwater level. Geocarto International, Vol. 30, No. 6, pp. 650-661.

[13] S. Guha, H. Govil, A. Dey and N. Gill, 2018. Analytical study of land surface temperature with NDVI and NDBI using Landsat 8 OLI and TIRS data in Florence and Naples city, Italy. European Journal of Remote Sensing, Vol. 51, No. 1, pp. 667-678.

[14] A. Varshney, 2019. Improved NDBI differencing algorithm for built-up regions change detection from remotesensing data: an automated approach. Remote Sensing Letters, Vol. 4, No. 5, pp. 504-512.

[15] NASA, "Global Warming," 03 June 2010. https://earthobservatory.nasa.gov/features/GlobalWarming/page2.php

[16] B. Ahmed, M. Kamruzzaman, X. Zhu, M. S. Rahman, and K. Choi, 2013. Simulating Land Cover Changes and Their Impacts on Land Surface Temperature in Dhaka, Bangladesh. Remote Sensing, Vol. 5, No. 11, pp. 5969-5998.

[17] D. R. Raja, 2012. Spatial Analysis of Land Surface Temperature in Dhaka Metropolitan Area. Journal of Bangladesh Institute of Planners, Vol. 5, pp. 151-167.

[18] N. S. Parvin and D. Abudu, 2017. Estimating Urban Heat Island Intensity using Remote Sensing Techniques in Dhaka City. International Journal of Scientific \& Engineering Research, Vol. 8, No. 4, pp. 289 - 298.

[19] M. B. Mia, R. Bhattacharya, and A. Woobaidullah, 2017. Correlation and Monitoring of Land Surface Temperature, Urban Heat Island with Land Use-Land Cover of Dhaka City Using Satellite Imageries. International Journal of Research in Geography (IJRG), Vol. 3, No. 4, pp. 10-20.

[20] S. Ara, M. A. Islam, and S. Showkat, 2016. Effect of land-use intensity on surface temperature: A study on Chittagong city corporation area," in IEEE Xplore Library.

[21] A.-A. Kafy, A.-A. Faisal, M. M. Hasan, M. S. Sikdar, M. H. H. Khan, N. Rahman, and R. Islam, 2019. Impact of LULC Changes on LST in Rajshahi District of Bangladesh: A Remote Sensing Approach. Journal of Geographical Studies, Vol. 3, No. 1, pp. 11-23.

[22] G. Grigoraș and B. Urițescu, 2019. Land Use/Land Cover changes dynamics and their effects on Surface Heat Island in Bucharest, Romania. International Journal of Applied Earth Observation and Geoinformation, Vol. 80, pp. 115126.

[23] H. Xu, 2006. Modification of normalized difference water index (NDWI) to enhance open water features in remotely sensed imagery. International Journal of Remote Sensing, Vol. 27, No. 14, pp. 3025-3033.

[24] W. C. Snyder, Z. Wan, Y. Zhang and Y.-Z. Fenz, 1998. Classification-based emissivity for land surface temperature measurement from space. International Journal of Remote Sensing, Vol. 19, No. 14, pp. 2753-2774. 
[25] S. Guha, H. Govil, A. Dey and N. Gill, 2018. Analytical study of land surface temperature with NDVI and NDBI using Landsat 8 OLI and TIRS data in Florence and Naples city, Italy. European Journal of Remote Sensing, Vol. 51, No. 1, pp. 667-678.

[26] H. West, N. Quinn, and M. Horswell, 2019. Remote sensing for drought monitoring \& impact assessment: Progress, past challenges and future opportunities, Remote Sensing of Environment. Vol. 323, p. 111291.

[27] M. Sahana, R. Ahmed and H. Sajjad, 2016. Analyzing land surface temperature distribution in response to land use/land cover change using split window algorithm to land use/land cover change using split window algorithm and spectral radiance model in Sundarban Biosphere Reserve, India. Modelling Earth Systems and Environment, Vol. 81, No. 2.

[28] A. -. A. Kafy, A.-A. Faisal, M. M. Hasan, Abdullah-Al- Faisal, M. Islam, and M. S. Rahman, 2020. Modelling future land use land cover changes and their impacts on land surface temperatures in Rajshahi, Bangladesh. Remote Sensing Applications: Society and Environment, Vol. 18, No. 2.

[29] S. M. T. Rahman and A. Kabir, 2019. Factors influencing location choice and cluster pattern of manufacturing small and medium enterprises in cities: evidence from Khulna City of Bangladesh. Journal of Global Entrepreneurship Research, Vol. 9, pp. 61-87. 